\title{
How Indians Used THE BIRCH
}

\author{
by M. A. WELSH*
}

The first European explorers to reach North America found the native Indians using many plants, one of which was the birch, (Betula papyrifera Marsh.) known variously as White Birch, Paper Birch and Canoe Birch. Its range was wide, covering every Canadian province, the northern United States and Alaska. It provided the Indians in these areas with many of their needs, particularly food, shelter and warmth.

The principal part of the birch used for food was the sap, collected in the spring and either drunk as it came from the tree or boiled down to form a syrup. This practice was widespread, especially in those areas which were outside the range of the Sugar Maple (Acer saccharum Marsh.).

This past summer Solomon Mirasty, a Cree Indian of Pelican Narrows, Saskatchewan, related to me the method his grandmother employed in tapping the tree for sap. Two cuts were made through the bark in the form of an inverted $\mathrm{V}$, with no cut across the bottom. The flap of bark thus formed was then drawn downward and formed into a trough through which the sap was directed to a birch-bark container placed beneath it. The collected sap was boiled down for about 24 hours until it formed a thick, black syrup which could be stored until needed, and was used as a sauce for fish and meat. Mrs. Nancy Ross, a Cree.Indian of La Ronge, Saskatchewan, has provided similar information, although she was not aware of the mechanics of tapping the trees. She stated that the syrup was used as a sauce for fish and bannock. Alfred Montegrand, a Chipewyan Métis, formerly of La Loche, also reports the use

* 501 25th St. W., Prince Albert, Saskatchewan. (Condensed from Saskatchewan Archaeology Newsletter 38:6-11, Sept. 1972) of birch syrup on fish and other foods. At Buffalo Narrows I have seen grove of birch trees with old tapping scars on them.

In addition to the sap, the cambium layer of the stem just under the bark was scraped off and eaten by Cree Indians. Angier recommends this as an emergency food which he states is pleasantly sweet and sustaining. ${ }^{\mathrm{He}} \mathrm{He}$ also reports that the twigs, young leaves and sapwood, when steeped in hot water, make an excellent beveragc with the aroma and flavor of wintergreen.

Many Indians made the bark into rolls for covering their dwellings. The trees, stripped for this purpose then died and dried out rapidly, providing a good source of fuel the following year for heating and cooking. Birchbark has been a traditional tinder for starting fires throughout the forested area and the entire tree can be used for fuel while it is green. It is one of the few woods that will burn without seasoning; it burns slowly and holds a fire for many hours, an advantage when heat is required all night for warmth.

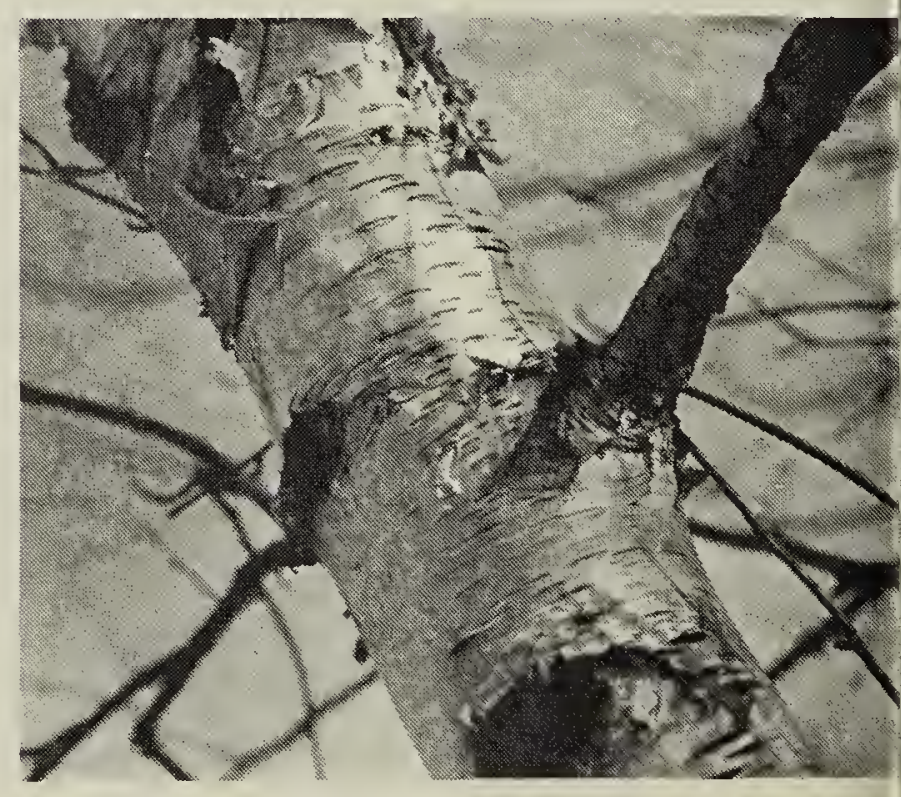

White Birch. 
to the Ojibwa, but Wintemberg reported graphic representations of the Thunderbird on birch bark by Dakota, Ojibwa, Plains Cree and Menomini Indians. $^{17}$

Many Indians wrapped their dead in birch bark before burial. ' ${ }^{\circ}$ In October, 1967, I examined and photographed two Indian burials at Cumberland House, Saskatchewan. These corpses had been wrapped in birch bark. A partially excavated burial in the archaeological laboratory in Saskatchewan shows evidence of birchbark wrapping. Mr. Harry Moody of Denare Beach reports that bodies unearthed near Pelican Narrows were wrapped in birch bark.

Gilmore reports that in the Missouri River Region finely-shredded birch bark was bound tightly in bundles and used as torches. ${ }^{4}$

The inner bark of the birch produced a brownish dye that required no mordant and gives a light brown colour to wool. ${ }^{11} 14$

Many tribes used the birch for medicine. The Ojibwa and Forest Potawatomi used the roots and twigs to obtain an aromatic oil for flavouring to mask unpleasant tastes in medicines. ${ }^{14}$ 1.5 The Seneca and Abenaki Indians used it in medicine to expel gas from the stomach.13 The Chippewa cured stomach aches with it, ${ }^{3}$ and the Cree used the wood with other materials to cure gonorrhea. A Cree-Métis of Buffalo Narrows described the procedure. Chips from the south side of Black Poplar (Populus tacamallacea Mill.), White Poplar or Aspen (Populus tremuloides Michx.) and birch, in equal quantities are bundled together with five stems of horsetail (Equisitum Sp.) and boiled three times in three successive waters in a lard pail. The entire quantity of each water is consumed. This treatment is said to cure gonorrhea in 5 days.

In formal medicine, tar extracted from birch bark has been used to treat skin conditions, the inner bark to reduce fevers, and the leaves to treat gout, rheumatism and dropsy."

Spore tubes or a fungus (Forne fomentaris (Fr.) ) which grows on bircl trees were burned slowly on a patient' joints to treat rheumatism by the Cre and Maliseet Indians. This materia was also used as tinder in fire making

To the Chippewa the birch is sacred first because of its many uses and second because of the legend concerning Winebojo. After he had killed the young of the Thunderbirds, Winebojo fled and found safe refuge in a hollow birch log. After the Thunderbirds left he came out of the $\log$ and declared that henceforth this tree would be a benefit to the human race. As a result, the tree is never struck by lightning and the bark is the last part of the tree to decay. The short marks on the bark were made by Winebojo but the "pictures" on the bark are pictures of little thunderbirds.

It is doubtful if any other plant has been used by more people for more purposes than the birch. It has been a part of the culture of all the people who lived within its range.

'ANGIER, Bradford. 1956. Ford from the flora Beaver. Autumn, 1956 (p. 25)

"BROWNLOW, C. V. 1941. Gould's medical dictionary, 5th edition. (p. 200).

"DENSMORE, Frances. 1927. Uses of plants by the Chippewa Indians. Bureau of American Ethnology, 33rd. Ann. Rep. (p. 390 and 288).

'G1LMORE, M. R. Use's of plants by the Indians of the Missouri River regiom. Bureau of American Ethnology, 33rd. Ann. Rep. (p. 75)

"HARRINGTON, Richard. 1963. Bitc a birc/lbark pattern. Can. Geong. Jour. 66:130-131.

"HOFFMAN, W. J. 1891. The medewinin or grand medicine society of the Ojibwa. Amcrican Burẹau of Ethnology. 7th Ann. Rep. (p. 99).

JENNESS, Diamond. 1929. Notes (m) the Berthuk Indians of Newfoundland. Nat. Museum Canada Ann. Rep. 1927. (p. 36).

'JENNESS, Diamond. 1929. The Ojibwa Indians of Parry Island. Nat. Museum Canada, Bul. 78. (p 57).

"JENNESS, Diamond. 1962. Camada's debt to the Indians. Can. Geog. Jour. 65:115.

"LEE-WHITING, B. B. 1966. Danial Sarazin still makes birch-bark camos. Can. Geog. Jour. 72:124.

"MATSON, Jessie. 1934. Indian regetable dyes. Part 1. Denver Art Museum. (p. 51). 
1:MOODY, Harry. 1957. Birch-bark biting. Beaver. Spring, 1957. (p. 9).

PARKER, A. C. 1928. Indian medicine and medicinc men. 36 Ann. Archaeological Rep. Ontario. (p. 1l).

'SMITH, H. H. 1932. Et/meshotaly of the Ojibwa Indian.s. Milwaukee Public Museum. (p. 413, 425 and 358 ).
1.5MITH, H. H. 1933. Ethmobentany of the Forest Prnawutomi Indians. Milwaukee Public Museum. (p. 43 ).

"SPECK, F. G. 1941. Art processes in hirch-bark of the River Desert Algomquin, a circumbereal trait. Bur. Amer. Ethnology, Bul. 128. (p. 250).

"WINTEMBERG, W. J. 1928. Representations of the Thunderbird in Indian art. 36 Ann. Rep. Archaeology, Ontario. (p. 28).

\title{
THE LAND, THE BIRDS
}

\section{Through 50 Years In Aspen Parkland}

\author{
by WILLIAM NIVEN*
}

My parents and uncle, originally from Scotland, moved from Winnipeg to our homestead in the aspen parkland, 5 miles north of Sheho in July, 1910. I was about 4 years old, and my brother George about 2. My brother and I still work together, farming the original 2 quarter-sections and about 5 more which we acquired later. We raise mostly beef cattle, growing also feed grain, for which this immediate district is best suited.

I became interested in nature, especially birds, while attending Newburn country school. Some of the teachers and some of the boys were also interested and I learned from them. Since then, I have simply observed the birds as I went about my daily farm work or on trips to Sheho, Invermay or Foam Lake.

My first bird identifications were based on Nuttall's "A Popular Handbook of the Birds of the United States and Canada", obtained in 1920, and later on Taverner's "Birds of Canada", bought in 1943. I have had binoculars for about 15 years.

Most years 1 recorded only spring migration dates for each species, although I have a few fall dates. I had recorded 86 species by 1924,140 by 1943, and my list now includes 181 species.

Sheho, Sisk.

\section{The Land}

Before the arrival of the white man, wildlife had been relatively undisturbed. The Indians took buffalo and other animals for food and trapped others for the fur-trade. With the change to agriculture, the environment changed greatly. Some species adapted, some so well that they increased noticeably, while others decreased.

In the parkland north of Sheho, there was a greater variety of plant and animal life in the early 1900's than on the open prairie. For this reason, the changes with settlement affected more species here.

When we arrived, the country was fairly heavily treed in places, mainly along the creeks, with trembling aspens, balsam poplars and willows. There were many large open grassy areas around lakes and marshes, as well as on the lighter sandy or gravelly lands. The amount of open area varied greatly from one quarter-section to another. Some land had very little bush and was readily broken for cultivation but the better land was usually $50 \%$ to $75 \%$ bush. The average in this district was about twothirds open land and one-third treed.

At first, only the best of the open land was broken by the plough Gradually fields were enlarged by 